\title{
CONSTITUTIONAL ASPECTS OF TEACHER DISMISSALS
}

\section{INTRODUCTION}

It is common ground among civil libertarians that there must, in a pluralistic society, be protection for minorities against the tyranny of the majority. The quality of a democracy is often said to be measured by the treatment which it affords its minorities. Protection of minorities, however, may work a tyranny against other minorities or individuals who may be affected by the actions of the protected minority class. Thus a balance has to be struck between conflicting rights.

In the case of Re Essex County Roman Catholic Separate School Board and Porter et al (1977) 78 D.L.R. (3d) 417, an Ontario Divisional Court was faced with just such a situation. ${ }^{1}$ Two teachers employed by the separate school board contracted civil marriages. As a result, their employer dismissed them on the ground that their conduct publicly and seriously infringed upon the denominational requirements of the school. Under s. 233(3) of the Education Act, S.0. 1974, c. 109, the teachers appealed to the Board of Reference. The school board disputed the jurisdiction of the Board of Reference on the ground that the school board had powers reserved to it by Section 93 of the British North America Act, 1867 that went beyond the terms of the written contract. The Board proceeded and reinstated the teachers.

On application for judicial review, the Divisional Court set aside the decision of the Board of Reference and held the provisions of the Ontario statute ultra vires since the right to dismiss for denominational reasons was a right or privilege with respect to denominational schools. Weatherston, J., for the majority, said, ${ }^{2}$

But it seems to me that there may be cases where a teacher in a separate school, although not guilty of conduct sufficient in law to justify dismissal for cause, may, by his conduct or teaching make his continued employment on the teaching staff intolerable.

Steele, J., in dissent, was of the opinion that school teachers of such schools were also a class of persons protected by section $93(1)$ of the British North America Act, 1867 and that the question as to the rights they had at the time of the union should also be examined. ${ }^{3}$ He concluded,

Nowhere can I find anything which specifically reserves any special rights to the trustees of a separate school with respect to their teacher's employment over and above whatever rights there were to the trustees of a common school.

It is the purpose of this paper to examine denominational rights of school boards as they relate to teachers and seek to draw some conclusions as to the comparative situations in various provinces but particularly in Alberta.

1. There is now an appeal decision in the Ontario Court of Appeal, September 18, 1978 as yet unpublished.

2. Re Essex County Roman Catholic Separate School Board and Porter et al. (1977) 78 D.L.R. (3d) 417 at 423.

3. Id., at 427.

4. Id., at 428. 


\section{DENOMINATIONAL SAFEGUARDS IN THE CONSTITUTION}

\section{A. The British North America Act, 1867}

The basic position of denominational schools in Canada is outlined in $\mathrm{s.} 93$ of the British North America Act, 1867 which provides:

93. In and for each province the Legislature may exclusively make Laws in relation to Education, subject and according to the following Provisions:

(1) Nothing in any such Law shall prejudicially affect any Right or Privilege with respect to Denominational Schools which any Class of Persons have by Law in the Province at the Union:

(2) All the Powers, Privileges, and Duties at the Union by Law conferred and imposed in Upper Canada on the Separate Schools and School Trustees of the Queen's Roman Catholic Subjects shall be and the same are hereby extended to the Dissentient Schools of the Queen's Protestant and Roman Catholic Subjects in Quebec:

(3) Where in any Province a System of Separate or Dissentient Schools exists by Law at the Union or is thereafter established by the Legislature of the Province, an Appeal shall lie to the Governor General in Council from any Act or Decision of any Provincial Authority affecting any Right or Privilege of the Protestant or Roman Catholic Minority of the Queen's Subjects in relation to Education:

(4) In case any such Provincial Law as from Time to Time seems to the Governor General in Council requisite for the due Execution of the Provisions of this Section is not made, or in case any Decision of the Governor General in Council on any Appeal under this Section is not duly executed by the proper Provincial Authority in that Behalf, then and in every such Case, and as far only as the Circumstances of each Case require, the Parliament of Canada may make remedial Laws for the due Execution of the Provisions of this Section and of any Decision of the Governor General under this Section.

\section{B. Judicial Interpretation of s. 93}

Decisions under the section seem to turn largely upon questions of fact, namely whether provincial legislation prejudicially affected rights or privileges of a specific religious minority in the province with respect to denominational schools which they had by law at the Union. ${ }^{5}$ In determining what would be the denominational rights with regard to any particular school, it is necessary first to determine whether or not the school is denominational and secondly to examine the laws in force at the time of the Union to ascertain if any such school then existed at law. It then becomes necessary to determine if the rights are (a) affected (b) prejudicially, by the impugned legislation. ${ }^{6}$ Thus, in New Brunswick, it was contended in argument that the de facto existence of denominational schools at the time of Union gave rise to denominational rights. The Privy Council, however held that, ${ }^{7}$

What might be an accidental result of the mode of working the Act under the old system is not to give a legal right to that denomination which was the right alone which was intended to be protected by the Federation Act of the Dominion of Canada ....

5. Ex Parte Renaud (1873) 14 N.B. (1 Pugs) 273.

6. Id., at 294-298.

7. Maher v. Town of Portland before the P.C. July 17, 1874; Wheelers Confederation Law, at 362-7 being an appeal from Ex Parte Renaud, supra n. 5. 
In 1874 then, whatever separate schools may have existed in practice at the Union in New Brunswick, none existed at law, and therefore the Common Schools Act adopted by the province in 1871 was constitutional. In Trustees of the Roman Catholic Separate Schools of Ottawa v. Ottawa Corporation, ${ }^{8}$ regulations prescribing how schools were to be conducted were held to be ultra vires as prejudicially affecting the right or privilege of a minority to manage its own schools. However, this was so because the penalty for non-compliance was closure of the school.

A province should be able to adapt legislation to new situations without prejudicially affecting denominational rights. Thus in Hirsch v. Protestant Board School Commissioners of Montreal et al. ${ }^{9}$ Viscount Cave, L.C. commented, ${ }^{10}$

S. 93 does not purport to stereotype the educational system of the Province as then existing. On the contrary, it expressly authorizes the provincial Legislature to make laws in regard to education subject only to the provisions of that section; and it is difficult to see how the Legislature can effectively exercise the power so entrusted to it unless it is to have a large measure of freedom to meet new circumstances and needs as they arise.

In Roman Catholic Separate School Trustees for Tiny Township and Others v. The King ${ }^{11}$ it was held, inter alia, that provincial legislatures do have the jurisdiction to regulate separate schools.

C. Modifications of S. 93

1. The Manitoba Act, 1870 (Canada) ${ }^{11_{a}}$

As new provinces entered Confederation, s. 93 was altered somewhat to adapt to local circumstances. Thus, the phrase "have by law" in s. 93(1) was changed by s. 22(1) of The Manitoba Act to read "have by law or practice". This seemed to take cognizance of the arguments going on at that time in New Brunswick, and recognized that no legally established separate school system existed at the time in Manitoba.

\section{The Manitoba School Question}

In the Manitoba Public Schools Acts, $1890^{12}$ the provincial government sought to abolish the denominational system of public education established by law since the Union. Aggrieved Catholic ratepayers argued that the legislation was ultra vires but the Privy Council held that the only "right or privilege" they enjoyed was that of establishing and maintaining for members of their own denomination such schools as they pleased. ${ }^{13}$ Then, the minority appealed to the Governor General in Council and the case was referred to the Supreme Court. The Supreme Court of Canada held that no such appeal lay from the said statutes and that the Governor General in Council had no power to make the orders sought. On appeal from the Supreme Court's decision, the Privy Council held that specified rights acquired after 1870 had been prejudicially affected and, while the legislation was not ultra vires, nevertheless the minority could appeal to the federal cabinet for remedial legislation. ${ }^{14}$ To this date no remedial legislation has been forthcoming.
8. [1917] A.C. 76 (P.C.).
9. [1928] 1 D.L.R. 1041 (P.C.).
10. Id., at 1052 .
11. (1928) 97 L.J.K.B. 69 (P.C.).
11a. 33 Vict., c. 3, s. 22 confirmed by s. 5 of the B.N.A. Act, 1871 (Imp.), 34 \& 35 Vict., s. 28.
12. 53 Vict. c. 37 and c. 38.
13. Winnipeg v. Barrett [1892] A.C. 445.
14. Brophy v. A.G. Man [1895] A.C. 202. 
3. British Columbia and Prince Edward Island

British Columbia joined Confederation on July 20, 1871, and Prince Edward Island on July 17, 1873, without any special provisions for denominational schools. Here, then, their status is once again dependent upon s. 93(1) which requires an examination of the status of denominational schools at Confederation.

In British Columbia the law at the time of the Union was to be found in the Common School Ordinance $1869^{15}$ and The Common School Amendment Ordinance $1870 .{ }^{16}$ The only right of denominational schools is that a minority may establish and maintain them.

In the Perepolkin case ${ }^{17}$, involving a charge relating to truancy of a Doukhobour child, Smith J.A. commented, ${ }^{18}$

Even assuming that the provinces cannot legislate on religion, section 93 I think makes it clear that the mere fact that bona fide legislation on education may indirectly affect religion in some aspects does not affect its validity ....

Prince Edward Island did not have denominational schools supported by law at the Union, though it did have such schools supported by public funds in practice. Thus, supported by "gentleman's agreements", denominational schools continue to exist.

4. The Saskatchewan Act and the Alberta Act, 1905

The constitutional position of denominational schools has here been embodied in section 17 of the Saskatchewan Act ${ }^{19}$ and section 17 of the Alberta Act. ${ }^{20}$ The two are identical, as follows:

17. Section 93 of the British North America Act, 1867, shall apply to the said province, with the substitution for paragraph (1) of the said section 93, of the following paragraph: -

(1) Nothing in any such law shall prejudicially affect any right or privilege with respect to separate schools which any class of persons have at the date of the passing of this Act, under the terms of chapters 29 and 30 of the Ordinances of the Northwest Terrorities, passed in the year 1901, or with respect to religious instruction in any public or separate school as provided for in the said ordinances.

(2) In the appropriation by the Legislature or distribution by the Government of the province of any moneys for the support of schools organized and carried on in accordance with the said chapter 29 or any Act passed in amendment thereof, or in substitution therefor, there shall be no discrimination against schools of any class described in the said chapter 29.

(3) Where the expression "by law" is employed in paragraph 3 of the said section 93, it shall be held to mean the law as set out in the said chapters 29 and 30 , and where the expression "at the Union" is employed, in the said paragraph 3 it shall be held to mean the date at which this Act comes into force.

15. O.B.C. $1868 \cdot 69$, No. 21 .

16. O.B.C. 1870 , No. 5 .

17. Perepolkin v. Supt. of Child Welfare [1957]23 W.W.R. 592 (B.C. C.A.).

18. Id., at 599-600.

19. 1905 (U.K.) $4 \& 5 \mathrm{Edw}$. VII, c. 3 ,

20. 1905 (U.K.) 4 \& 5 Edw. VII, c. 42. 


\section{Judicial Interpretation of Alberta and Saskatchewan Provisions}

Chapter 30 of the Northwest Territories Ordinances, An Act Respecting Assessment and Taxation in School Districts, ${ }^{21}$ has been the subject of some litigation in both Saskatchewan and in Alberta. The case of McCarthy v. The City of Regina et al..$^{22}$ held the term "at the time of the Union" as used in s. 17(3) of the Saskatchewan Act (identical in the Alberta Act) to mean September 1, 1905. Thus, the denominational rights, as stated in c. 29 and 30 of the Ordinances determine the rights of denominational schools.

In $R$. v. Ulmer, these rights were examined by the Alberta Supreme Court, Appellate Division. This case involved the prosecution of a German Lutheran for not sending his child to a public school. Stuart J. A. concluded ${ }^{23}$

It is only the rights and privileges in respect to separate schools as given by the Ordinances of 1901 , chs. 29 and 30 whatever they were, which are protected and preserved. A reference to secs. 41 et seq., of the former Ordinance shews clearly that the right or privilege was the privilege of the minority in a district whether Protestant or Roman Catholic to establish by law a separate school, to levy rates and assessments upon themselves for the maintenance thereof, and to be subject to ordinary governmen. tal control and inspection. A legally established system was in contemplation by which the minority were relieved from taxation to support a public school and empowered legally to levy rates upon themselves to support a separate school.

$\mathrm{He}$ also dealt with the phrase "any right or privilege with respect to denominational schools" and said ${ }^{24}$

In my opinion those words refer to a legal right or privilege, i.e. a right or privilege established by law and granted specially to a distinctly specified "class of persons" who have been set apart from the rest of the community by the law which has conferred the right or privilege upon them. [my emphasis]

In Saskatchewan and Alberta, there is a clear right for a minority in a school district to establish separate schools. The majority, whether Catholic or Protestant, are thus within a public system, and those whose views differ may administer a separate school system and pay taxes accordingly.

6. Newfoundland - Terms of Union, s. 17, 1949

Under the Terms of Union of Newfoundland with Canada, $1949^{25}$ it is provided

17. In lieu of section ninety-three of the British North America Act, 1867, the following term shall apply in respect of the Province of Newfoundland:

In and for the Province of Newfoundland the Legislature shall have exclusive authority to make laws in relation to education, but the Legislature will not have authority to make laws prejudicially affecting any right or privilege with respect to denominational schools, common (amalgamated) schools, or denominational colleges, that any class or classes of persons have by law in Newfoundland at the date of Union, and out of public funds of the Province of Newfoundland, provided for education,

(a) all such schools shall receive their share of such funds in accordance with scales determined on a non-discriminatory basis from time to time by the Legislature for all schools then being conducted under authority of the Legislature; and

21. O.N.W.T. 1901 c. 30.

22. [1917] 1 W.W.R. 1105.

23. [1922] 1 D.L.R. (NS) 304 at 321.

24. Id., at 323 .

25. Confirmed by B.N.A. Act, 1949 (U.K.) 12 - 13 Geo VI, c. 22. 
(b) all such colleges shall receive their share of any grant from time to time voted for all colleges then being conducted under authority of the Legislature, such grant being distributed on a nondiscriminatory basis.

It will be noted that no provision is made for remedial legislation from the Federal Parliament. It is necessary though to examine the rights in existence "at the time of the Union". In 1949 there were, by law, six types of denominational school districts; United Church, Roman Catholic, Anglican, Salvation Army, Pentecostal Assemblies and Amalgamated. About one-third of the students were Anglican, slightly above one-third Roman Catholic, the remaining one-third being with the others. ${ }^{26}$ All such schools under section 17(a) thus receive public funds on a nondiscriminatory basis. There appears to be little or no litigation in the area. D. The Basic Situation - Provincial Variations

Summarizing to this point, a number of variations are evident from province to province. Generally,

(1) A denominational minority, as defined upon the province's entry into Confederation, may assume responsibilities, within limitations, at public cost for the provision of education in Ontario, Quebec, Saskatchewan, Alberta and Newfoundland.

(2) Elsewhere, denominational schools may exist, but do not receive government financial support or tax exemption from the support of the public school system for their adherents. ${ }^{27}$

\section{Judicial Principles}

A number of principles for the interpretation of the constitutional rights of the denominations as they might affect the employment of teachers might be gained from the cases reviewed.

(1) Denominational rights guaranteed in the constitution were those rights existing at law at the time the Province in question joined Confederation. $^{28}$

(2) A province should be able to adapt legislation to new situations without prejudicially affecting denominational rights. ${ }^{29}$

(3) Provincial legislatures do have the jurisdiction to regulate separate schools but not if it would result in their closure..$^{30}$

(4) Even where the rights are prejudicially affected, the provincial legislation may not be ultra vires, and the appropriate course for the minority is to appeal to the federal cabinet for a remedy (except in Newfoundland because of the Terms of the Union). ${ }^{31}$

(5) Religion can be differentiated from certain codes of ethics, conduct or manners and such codes cannot be part of the religion. ${ }^{32}$

(6) The mere fact that bona fide legislation on education may indirectly affect religion does not affect its validity. ${ }^{3 s}$

26. The Organization and Administration of Public Schools in Canada (2d ed.) at 216.

27. McConnel, Commentary on the B.N.A. Act (1977).

28. Ex Parte Renaud, supra n. 5.

29. Hirsch v. Protestant Board School Commissioners of Montreal et al, supra n. 9.

30. Roman Catholic Separate School Trustees for Tiny Township and Others v. The King, supra n. 11.

31. Brophy v. A.G. Man., n. 14.

32. Perepolkin v. Supt. of Child Welfare, supra n. 17.

33. Id. 
(7) In Alberta and Saskatchewan the rights of denominational schools were conferred [my emphasis] by c. 29 and 30 of the Northwest Territories Ordinances. ${ }^{34}$

\section{CONFLICT RESOLUTION IN TEACHER/SCHOOL BOARD DISPUTES IN ALBERTA}

\section{A. Boards of Reference under The School Act}

Where school boards and individual teachers often come into conflict in employer/employee situations, most provinces seem to have established statutory rights of appeal to Boards of Reference or some similarly constituted quasi-judicial body. As administrative tribunals, they are subject to judicial review. Usually, the Board of Reference is not a court of record, but it would seem that the vast majority of cases appearing before it involve appeals by teachers of a school board dismissal, termination of designation (eg. as principal) or transfer. In Alberta, the Board of Reference operates under s. $84-90$ of the School Act, R.S.A. 1970, c. 329 as amended to 1977 , which provides that, where a disagreement arises between a board and a teacher with respect to termination of a contract, termination of a designation or refusal of a board to release a teacher, the teacher may appeal to the Minister who shall refer the matter to the Board of Reference. Section 87 of the School Act provides that the Board shall investigate and give both parties an opportunity to be heard. It may make such order as it considers just with respect to the appeal. Generally, it may order that the school boards ruling be changed, it may order reinstatement, order damages or order that no salary be paid for a specific time, or confirm the action of the school board.

Teachers' contracts with school boards are subject to the rules laid down in s. 73 - 83 of the School Act. ${ }^{35}$ Section 73 provides that a board shall only employ teachers qualified under the Department of Education Act. ${ }^{36}$ Section 75 provides for transfers of teachers and provides for an appeal of a transfer to the school board. Section 78 provides for termination by a board of a teacher. There must be 30 days clear notice, reasons must be given and the board must act reasonably. The board may suspend a teacher with pay who has been served with notice of termination. Section 79 provides for suspension of a teacher where the board on reasonable grounds believes the teacher has been guilty of gross misconduct, neglect of duty or refusal or neglect to obey a lawful order of the board, or the presence of the teacher is detrimental to the well being of the school by reason of mental infirmity.

B. Constitutionality of Boards of Reference

Two questions arise with respect to the above provisions: -

1. How do they differ, if at all, from the provisions of c. 29 of the Ordinances of the Northwest Territories, 1901 ?

2. If they differ, can these provisions be interpreted as affecting, prejudicially, the rights of denominational schools as guaranteed under $\mathrm{s}$. 93(1) of the B.N.A. Act as modified by s. 17 of the Alberta Act?

34. R. v. Ulmer, supra n. 23.

35. R.S.A. 1970, c. 329.

36. R.S.A. 1970, c. 96. 
Chapter 29 of the Ordinances of the Northwest Territories ${ }^{37}$ provides in $\mathrm{s}$. 4 for control and mangement of all schools to be in the department. Section 7(1) provides for a commissioner to appoint one or more persons to have the power of inquiry into an appeal, complaint or dispute, and for him to make such order based upon inquiry as to him shall seem proper.

Under $\mathrm{s} .151$ the form of contract between the board and the teacher is specified and s. 153 gives a teacher the right of appeal from dismissal with the power of reinstatement in the commissioner.

The duties of the teacher include teaching, discipline, and a variety of matters related to the ordinary management of the schools under s. 158.

Separate schools are provided for under s. 41-45, the rights and powers of separate school districts under s. 45 being the same as provided for in public school districts - such powers (semble) being under s. 95. There was no statutory requirement that a board act reasonably.

\section{THE JURISDICTION OF THE ONTARIO BOARD OF REFERENCE}

The decision of Re Essex and Porter has recently been upheld in the Ontario Court of Appeal ${ }^{38}$ The essential points of the appeal decision were:

1) Nothing in the legislation in existence at the time of Union detracted from the trustees' common law rights as employer.

2) If a board can dismiss for cause, a denominational board can dismiss for denominational cause.

3) The power to dismiss for denominational cause is a "right or privilege with respect to denominational schools" under section 93 of the B.N.A.Act, 1867.

4) To subject the right to dismiss for denominational reasons to a review by a Board of Reference would prejudicially affect the right.

5) The Board of Reference has no jurisdiction to deal with the dismissals of teachers in this case because the Ontario legislature had no power to give it that jurisdiction.

\section{THE JURISDICTION OF THE ALBERTA BOARD OF REFERENCE}

\section{A. The Problem Stated}

The question as to whether the Alberta Board of Reference would similarly be acting outside of its jurisdiction in a situation similar to that in Essex, may well arise in the near future for a number of reasons. School boards are faced with declining school populations and in a number of instances are feeling compelled to reduce staff. Separate school boards in Alberta have in the past hired teachers who did not profess any particularly strong adherance to the religious tenets of the minority Board employing them. There is growing pressure upon trustees for more restrictive policies not only with regard to hiring of teachers, but also with regard to the conduct of teachers. Thus, officials report, there is increased concern about what some consider to be "outrageous conduct" - teachers openly living as homosexuals, in common law relationships, or in general not adhering to the tenets of the minority

37. The School Ordinance, O.N.W.T. 1901, c. 29.

38. Essex County Roman Catholic Separate School Board v.Porter and Podgorski, unreported, 28 Sept. 1978. 
denomination. Some of these pressures on Boards would seem to reflect similar movements in the United States. In California, for example a proposition is going to a referendum seeking to ban all homosexual teachers from practice as well as teachers openly sympathetic to homosexuality ${ }^{39}$ It would seem, if similar pressures do indeed exist in Alberta, that, at least in separate schools, if Re Essex is followed, a school board dismissing for denominational cause of this nature would not be subject to an appeal to a Board of Reference.

That such an interpretation is possible is supported by the Saskatchewan case of Board of Education for Moose Jaw School District No. 1 et al. v.A.G. Saskatchewan et al. ${ }^{40}$ where a provision for binding arbitration in The Teacher Collective Bargaining Act ${ }^{41}$ was held to be invalid because it involved one of the rights and privileges of a separate school board elsewhere preserved to it, namely the regulation and the selection of teachers. In that case, the impugned legislation provided for binding arbitration "in any matter involving disciplinary action by a school board against a teacher except dismissal".

\section{B. Common Law Rights or Statutory Rights}

The crux of the issue seems to lie in the interpretation of the words "under the terms of c. 29 and c. 30 " and "with respect to religious instruction as provided for in the said ordinances" in s. 17(1) of the Saskatchewan Act (cf The Alberta Act).

It would seem that upon the construction given this clause in the Moose Jaw case (at trial), the ordinance is restrictively construed so that if the statute did not specifically restrict common law rights, then impliedly they continued to exist, and, accordingly, any subsequent provincial legislation would be ultra vires if it prejudicially affected common law rights. This appears to be the interpretation given by the Ontario Court of Appeal in the Essex case to s. 93(1).

The opposite side of the argument is found in the dissent of Steele, J. in the Essex trial, where he said, ${ }^{42}$

Nowhere can I find anything which specifically reserves any special rights to the trustees of a separate school with respect to their teacher's employment over and above whatever rights there were to the trustees of a common school.

Although the view of Steele, J. was overruled by the Ontario Court of Appeal, it may well be argued that his view has greater applicability in Saskatchewan and Alberta for the reason that the sections 17(1) of the respective Acts creating the latter two provinces spoke in terms that conferred rights under the terms of c. 29 and c. 30 of the Northwest Territories Ordinances as opposed to the general clause in s. 93(1) of the B.N.A. Act which preserved rights which any class had by law. ${ }^{3}$ Thus, under c. 29 a denominational board was subject to appeal to the commissioner who did have the power to reinstate the teacher. ${ }^{44}$ It is submitted

39. Since the time of writing, the Bill, Proposition 16 was defeated in the California Referendum, Tuesday, November 7, 1978.

40. (1973) 41 D.L.R. (3d) 732, [1974] 2 W.W.R. 27; varied (1975) 57 D.L.R. (3d) 315, [1975] 6 W.W.R. 113.

41. S.S. 1973 , c. 112.

42. Id., at 428.

43. See $R$. v. Ulmer supra n. 23 at 323.

44. 8. 153 , c. 29 supra n. 37. 
that a Board of Reference, insofar as it replaces the commissioner, may thus review a school board's actions in dismissing a teacher for denominational reasons, for, even under the Ordinance, denominational reasons for dismissal were, in Alberta and Saskatchewan, subject to change by the Commissioner. Thus, unlike Ontario, the common law rights of denominational boards to dismiss for denominational reasons were restricted by the 1901 Ordinances. Therefore, provided that these rights are not further restricted by subjecting them to review by the Board of Reference, then it can hardly be said that they are prejudicially affected.

Present day practice in Alberta and Saskatchewan seems to indicate that Boards of Reference are generally exercising jurisdiction in disputes involving dismissal of teachers. As yet, it does not appear that the question of jurisdiction in denominational matters has been raised. In a fact situation in Alberta similar to that in Re Essex, it is submitted that the constitutional argument that was used to rule the reinstatement by the Board of Reference ultra vires ought to be unsuccessful in the light of a careful construction of the Alberta Act, s. 17 and the Ordinances of the Northwest Territories. Therefore, if separate school boards require a type of conduct from their teachers different from that required by other boards, it may be worth examining the possibility of clarifying teacher duties, rights and obligations in their various contracts and policies.

Even if the Alberta Board of Reference were to be ruled as acting ultra vires in questions involving denominational rights, this does not mean, of course, that separate school boards' actions are immune from review. As Zuber, J. remarked in the Essex appeal ${ }^{45}$

It remains only to say that teachers are not without recourse. They have the right to resort to the courts and ask for damages on the basis that they were wrongfully dismissed if such was the case.

\section{CONCLUSION}

Where a Board of Reference attempts to infringe upon denominational rights which were conferred by c. 29 and c. 30 of the Northwest Territories Ordinances, clearly it will be acting outside of its jurisdiction. It is less clear that it would be so if it infringed upon common law rights existing as of the time of the Union. Much depends upon how the courts will construe the Ordinances. If they are construed as conferring the only denominational rights to exist, then it is argued, by implication, that no common law denominational rights outside of those conferred exist. On the other hand, if the Ordinances can be said to extend denominational rights, then equally,by implication, common law denominational rights over and above those rights enjoyed by public schools do exist, and a Board of Reference could be outside of its jurisdiction if it sought to deal with such issues.

Brian L. Fish*

45. Supra n. 38 at p. 6.

* B.A., B.Ed., M.Ed. (Ed. Admin.), LL.B., University of Alberta. 